\section{Evaluation of growth potential and growth dynamics of Listeria monocytogenes on ready-to-eat fresh fruit}

\author{
David Collu, ${ }^{1}$ Luisa Marras, ${ }^{1}$ \\ Adriana Sanna, ${ }^{1}$ Gerolamo Carrucciu, ${ }^{1}$ \\ Antonella Pinna, ${ }^{1}$ Valentina Carraro, ${ }^{1}$ \\ Giuseppina Sanna, ${ }^{2}$ Valentina Coroneo ${ }^{1}$ \\ ${ }^{1}$ Department of Medical Sciences and \\ Public Health, University of Cagliari; \\ ${ }^{2}$ Department of Biomedical Sciences, \\ University of Cagliari, Cagliari, Italy
}

\begin{abstract}
The consumption of fresh or RTE fruits is increasing every year and Listeria monocytogenes has been identified on raw or minimally processed fruits. A food product can become contaminated with $L$. monocytogenes anywhere along the pathway of food production during planting, harvesting, packaging, distribution and serving. The aim of this work was to assess the microbiological risks associated with consumption of ready- to- eat fruit such as melon, pineapple, coconut and fruit salad. The presence of Escherichia coli, Salmonella spp. and L. monocytogenes was also evaluated. Microbiological challenge tests were carried out for the evaluation of the L. monocytogenes growth potential in RTE fruit stored at 4 and $8^{\circ} \mathrm{C}$. E. coli counts resulted under the detection limit of $10 \mathrm{CFU}$ $\mathrm{g}^{-1}$, Salmonella and L. monocytogenes were not detected (absence in $25 \mathrm{~g}$ ). The growth potential values in coconut and melon $(\delta>0.5)$ showed the growth capacity of Listeria at the temperatures considered. A low initial load, also derived from good hygiene practices, and correct storage temperatures are essential to reduce bacterial growth in RTE fruit. The challenge test showed how each type of RTE fruit has a different commercial life based on its specific growth potential and that food should be stored at temperatures not higher than $4^{\circ} \mathrm{C}$ for a short period.
\end{abstract}

\section{Introduction}

L. monocytogenes is a ubiquitous and invasive (Kocks et al., 1992; Dussurget, Pizarro-Cerda, \& Cossart, 2004) food-borne pathogen, responsible for listeriosis in humans.

This microorganism causes many diseases, ranging from mild gastroenteritis to severe blood and central nervous system infections, and can result in a high fatality rate in immune-compromised populations and the elderly. In pregnant women, infection can lead to miscarriage, premature birth or infection of the newborn (Drevets \& Bronze, 2008). The incubation period of listeriosis occurs generally within 28 days (Angelo et al., 2016). In 2018, 28 European countries reported 2549 confirmed cases of listeriosis. Almost all (42.4\%) listeriosis cases were hospitalised in 2018 and 229 were fatal (ECDC, 2018).

More than $90 \%$ of invasive listeriosis is supposed to be caused by the ingestion of RTE food, and one-third of cases are due to growth in the marketing phase (Ricci, Allende, Bolton, Chemaly \& Davies, 2018).

L. monocytogenes is broadly distributed in natural environments and has a marked capability to survive under stress conditions over food-processing and produce-packaging settings and equipment (Taormina \& Beuchat, 2002). A food product can become contaminated with L. monocytogenes anywhere along the food production pathway (planting, harvesting, packaging, distribution, serving) (Silva, Teixeira, Oliveira, \& Azeredo, 2008) because of strong adaptive capacity and due to inappropriate hygiene conditions (Ricci, Allende, Bolton, Chemaly, \& Davies, 2018).

RTE foods and cold-stored products (principally meat and dairy) are commonly considered high-risk foods for L. monocytogenes infections ( $\mathrm{Zhu}$, Gooneratne, \& Hussain, 2017). RTE foods are processed so that they are RTE without any additional handling steps (Bencardino, Vitali, \& Petrelli, 2018). Nevertheless, RTE vegetables and fruits might represent a potential danger for human health due to the high risk of growth of undesirable microorganisms (Beuchat, 1996; Salazar et al., 2017).

Several outbreaks were reported involving raw and processed vegetables and RTE foods due to L. monocytogenes contamination in many countries (Zhu, Gooneratne, \& Hussain, 2017; Buchanan, Gorris, Hayman, Jackson, \& Whiting, 2017). The 2011 cantaloupe outbreak determined 143 hospitalisations and 33 deaths (McCollum et al., 2013). The 2014-2015 multistate L. monocytogenes outbreak related to caramel apples caused 35 illnesses in 12 states including 7 deaths (Angelo et al., 2017). Moreover, there were several L. monocytogenes recalls related to fresh apples, sliced apples, and stone fruits including whole peaches, nectarines, plums, and pluots (Sheng, Edwards, Tsai, Hanrahan, \& Zhu, 2017).

In particular, the consumption of RTE fruits is increasing every year, and L. monocytogenes has also been detected on raw or
Correspondence: Valentina Coroneo, Department of Medical Science and Public Health, University of Cagliari, Italy, University Campus, I-09042 Monserrato, Cagliari, Italy.

Tel.: +39.070.6758379 - Fax +39.070.6758373

E-mail: coroneo@unica.it

Key words: Listeria monocytogenes, ready-toeat (RTE), fresh fruit, challenge test, Growth Potential.

Contributions: DC and VC: designed the study, interpreted the results and critical appraisal and editing of the manuscript. GC and AP: maintained the isolates, the strains, prepared cultures and performed culture media. LM and GS: assisted in writing the paper and in the critical analysis of the manuscript. AS: analyzed the experimental data and critical analysis of the manuscript. VC editing final presentation. All authors have read and approved this manuscript.

Conflict of interest: The authors declare no potential conflict of interest.

Funding: None.

Received for publication: 3 September 2020 Revision received: 27 December 2020. Accepted for publication: 22 March 2021.

This work is licensed under a Creative Commons Attribution-NonCommercial 4.0 International License (CC BY-NC 4.0).

(C) Copyright: the Author(s), 2021

Licensee PAGEPress, Italy

Italian Journal of Food Safety 2021; 10:9337

doi:10.4081/ijfs.2021.9337

minimally processed fruits (Bae, Seo, Zhang, \&Wang, 2013).

This work explored the growth potential and growth dynamics related to L. monocytogenes in fresh-cut minimally processed fruit (melon, pineapple, coconut and fruit salad). We also characterised the microbiological profiles (E. coli, Salmonella and $L$. monocytogenes) in order to verify compliance with the legal limits (Table 1).

\section{Materials and Methods}

\section{Microbiological profiles RTE fruits}

L. monocytogenes growth was investigated in different vegetal RTE matrices: coconut (Cocos nucifera), fruit salad (grapes, kiwi, melon and pineapple), pineapple (Ananas sativus), melon (Cucumis melovar. piel de sapo) and melon (Cucumis melovar. cantalupo) which were purchased from local supermarkets. The 
fresh-cut fruit was packed in transparent plastic-sealed tray packaging, stored in air (not in a modified atmosphere or under vacuum). The shelf-life indicated by the producer was 4 days by storing at displayed temperature under $8^{\circ} \mathrm{C}$. The samples, of various shapes and sizes, presented a net weight between $120 \mathrm{~g}$ and $300 \mathrm{~g}$.

The study was conducted on 42 RTE fruits (melon n. 6 packs, coconut n. 6 packs, fruit salad n. 15 packs, pineapple n. 15 packs) collected from local retail shops during year 2019 in south Sardinia. Samples were randomly selected from three different batches. The RTE fruit samples were packed in flexible packaging, transported to the laboratory and stored at $4 \pm 2^{\circ} \mathrm{C}$ until the experiment was performed. Experimental samples were defined as the RTE fruit samples artificially contaminated with L. monocytogenes. Control samples were defined as the non-inoculated units and used to evaluate the natural presence of $L$. monocytogenes in RTE fruit samples from the batches used in our experiment. During the work, the testing times (T) were defined as T0, which was $6 \mathrm{~h}$ after inoculation, and T1, T2, T3, T4 and T5 which were, respectively, the analysis points every 2 days for a total of 10 days after inoculation.

Following EC Reg. 2073/2005 microbial limits for fruit RTE, the presence of E. coli, Salmonella spp. and L. monocytogenes was evaluated. L. monocytogenes was detected according to UNI EN ISO 11290-1:2017 and the UNI EN ISO 11290-2:2017 method was used for enumeration, while enumeration of beta-glucuronidase-positive $E$. coli and Salmonella spp. was carried out following UNI ISO 16649-2:2010 and UNI EN ISO 6579-1:2017 respectively (Table 2).

\section{Water activity $\left(\mathrm{a}_{\mathrm{w}}\right)$ and $\mathrm{pH}$}

Water activity (aw) and the $\mathrm{pH}$ of the samples were measured using an aw Hygrometer Dew Point Water activity meter 4TE (AcquaLab) and a digital $\mathrm{pH}$ meter with a glass electrode $\mathrm{pH} 510$ Eutech Instruments (Cyberscan), following the manufacturer's instructions.

\section{Challenge test}

The study was performed according to the Technical Guidance Document prepared by the EU Community Reference Laboratory (CRL) for L. monocytogenes (Guidelines EURL 2004). A mixture of three L. monocytogenes strains was used to challenge RTE fruit units (Coroneo et al., 2016; Marras et al., 2019). The inoculum was composed of L. monocytogenes reference strain ATCC 35152 obtained from the American Type Culture Collection and two wild type strains previously isolated from the RTE fruit samples. All the strains were stored at $-80^{\circ} \mathrm{C}$ in Brain Heart Infusion (BHI) broth (Oxoid, Basingstoke, UK) with glycerol $(15 \%, \mathrm{v} / \mathrm{v})$. Separate trials were conducted to determine the growth conditions necessary to standardise the level of inoculum to approximately 10-100 CFU/g. Cultures were then adapted at refrigeration temperature by storing at $4 \pm 2^{\circ} \mathrm{C}$ for ten days. Prior to starting the experiment, a bead of each strain was surface plated onto a Petri dish with Trypticase Soy Agar (TSA, Microbiol Diagnostici, Uta, Cagliari, Italy) and incubated at $37^{\circ} \mathrm{C}$ for $24 \mathrm{~h}$. Then, a loopful of one isolated cell was transferred aseptically into $10 \mathrm{~mL}$ of $\mathrm{BHI}$ and incubated at $37^{\circ} \mathrm{C}$ overnight. To determine the initial concentration of each working cocktail, a suspension of approximately $1.5 \times 10^{8}$ $\mathrm{CFU} / \mathrm{mL}$ of $0.5 \mathrm{McF}$ arland $(\mathrm{McF})$ was prepared. Each working cocktail was diluted and mixed to obtain two "Challenge Working Culture" (CWC) of the three $L$. monocytogenes strains, approximately 0.9 $\log 10 / \mathrm{mL}$ and $2 \log 10 / \mathrm{mL}$ at the stationary phase. Colony counts were confirmed by plate count on TSA. Samples of $10 \mathrm{~g}$ RTE fruit were inoculated both with $100 \mu \mathrm{L}$ of CWC containing $2 \log 10 \mathrm{CFU} / \mathrm{ml}$ and 0,9 $\log 10 \mathrm{CFU} / \mathrm{ml}$ of L. monocytogenes suspension homogenised with a stomacher to simulate two different origins of contamination: one natural and the other associated with low levels of GMP by food sector operators even if from an anlitic point of view the first aspect examined is associated with a higher level of uncertainty attributable to lower counts (Bartholome, 2005; François, 2007; Hwang, 2007). Subsequently, 3 samples for each type of inoculated fruit samples were stored at two different temperatures, $4^{\circ} \mathrm{C}, 8^{\circ} \mathrm{C}$.

$4^{\circ} \mathrm{C}$ represents the correct temperature at which these foods should be maintained (or collected), whereas " $8{ }^{\circ} \mathrm{C}$ " should simu-

Table 1. Legal food safety criteria and process hygiene criteria for microbial limits in all ready-to-eat fruits.

\begin{tabular}{|c|c|c|c|}
\hline Parameter & Reference limits & Application of criteria & Reference \\
\hline E. coli & $10^{2} \mathrm{CFU} / \mathrm{g}$ & $\begin{array}{l}\text { Manufacturing process. } \\
\text { (Process hygiene criteria) }\end{array}$ & $\begin{array}{l}\text { EC N.2073-2005/ } \\
\text { DM n.3746-2014 }\end{array}$ \\
\hline Salmonella spp. & Absence in $25 \mathrm{~g}$ & $\begin{array}{l}\text { Products placed on the market during their shelf-life. } \\
\text { (Food safety criteria) }\end{array}$ & $\begin{array}{l}\text { EC N.2073-2005/ } \\
\text { DM n.3746-2014 }\end{array}$ \\
\hline L. monocytogenes & $\begin{array}{l}10^{2} \mathrm{CFU} / \mathrm{g} \\
\text { Absence in } 25 \mathrm{~g}\end{array}$ & $\begin{array}{l}\text { Products placed on the market during their shelf-life. } \\
\text { (Food safety criteria) } \\
\text { Before the food has left the immediate control of the } \\
\text { food business operator who has produced it } \\
\text { (Food safety criteria) }\end{array}$ & $\begin{array}{l}\text { EC N.2073-2005/ } \\
\text { DM n.3746-2014 } \\
\text { EC N.2073-2005/ } \\
\text { DM n.3746-2014 }\end{array}$ \\
\hline
\end{tabular}

Table 2. Assessment of growth potential test $(\delta)$.

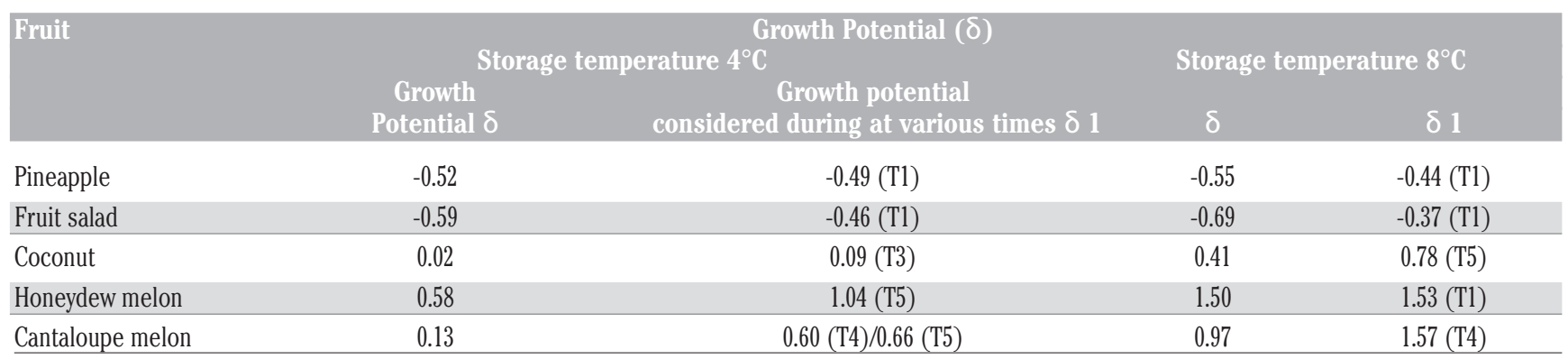


late the uncontrolled temperatures at which these products are often stored (i.e. during the cold chain or more often in household fridges, especially in the hot season when they are normally consumed). Negative control (sterile physiological water) were considered. The data are the mean values of the duplicate analysis of triplicate batches.

The challenge was carried out in independent trials for each batch performed one week apart. L. monocytogenes enumeration was conducted according to International Standard methods UNI EN ISO 112902:2017. For the L. monocytogenes enumeration, the samples were subjected to a 1:10 dilution in Fraser Broth base (Microbiol Diagnostici, Uta, Cagliari, Italy) and maintained at $20 \pm 2^{\circ} \mathrm{C}$ for $1 \mathrm{~h} \pm 5 \mathrm{~min}$. A $1 \mathrm{~mL}$ aliquot from initial suspension was directly streaked on three ALOA (Agar Listeria Ottaviani \& Agosti) and incubated at $37^{\circ} \mathrm{C}$ for 24 and $48 \mathrm{~h}$. After the incubation period, samples were taken using the typical colony count. For each time point, the results of the samples analysed were aggregated and reported as the median concentration of microorganisms expressed in $\log 10 \mathrm{CFU} / \mathrm{g}$.

Challenge tests assessing growth potential $(\delta)$ of $L$. monocytogenes were used (Gnanou Besse, Beaufort, Rudelle, Denis, \& Lombard, 2008). A measure for the potential risk posed to consumers by $L$. monocytogenes in a certain product is the growth potential $\delta$, defined as the difference between the $\log ^{10} \mathrm{CFU} / \mathrm{g}$ at the beginning and end of the products shelf life (Beaufort, Bergis, Lardeux \& Lombard, 2014). $\delta$ depends on the physical properties of the product, the storage temperature and the shelf life. The food samples were considered as supporting L. monocytogenes growth when the growth potential value was higher than $0.5 \log 10$. Any value lower than $0.5 \log 10$ wasconsidered as not supporting growth. $\delta 1$ is the maximum Growth Potential estimated during the whole period considered (ten days). To characterize the growth trend of L. monocytogenes during the shelf life, a growth potential was also evaluated between the various analytical times. Starting from time 0 (beginning of the incubation), the inoculated samples were analysed every 2 days for 4 days for $\delta$ evaluation (T0, T1, T2) and for 10 days for growth dynamics studies (from T0 to T5) This condition was considered in order to simulate a hypothetical consumption by consumers beyond the expiration date.

\section{Statistical data analysis}

All experiments were performed twice and repeated in triplicate. Therefore, the reported data represent the means of six values. Means and standard deviations (SD) were calculated in replicates within the experiments, and analyses were carried out using Microsoft Excel XP 2010.

\section{Results and Discussion}

$\mathrm{pH}$ and water activity were measured in the various types of RTE fruit. Fresh-cut pineapple showed average values of $\mathrm{pH}$ equal to $3.6 \pm 0.015$, while melon showed a $\mathrm{pH}$ equal to $5.58 \pm 0.018$. Average $\mathrm{pH}$ values of $3.74 \pm 0.015$ were found for fruit salad, while values of $6.27 \pm 0.006$ were found for coconut at the end of the shelf-life phase (Figure 1).

With regard to the average $\mathrm{a}_{\mathrm{W}}$ values, $0.989 \pm 0.0001$ values were recorded forpineapple, $0.991 \pm 0.0004$ for melon, while fruit salad and coconut showed $\mathrm{a}_{\mathrm{W}}$ values of $0.998 \pm 0.0003$ and $0.990 \pm 0.0008$, respectively (Figure 2). The data shown for melon represent the mean of results detected for the two different samples (var. piel de sapo and var. cantaloupe).

L. monocytogenes growth results agree with the association of favourable factors, referred to ecological parameters such as water activity and hydrogenionic concentration. High water activity measured in RTE products always resulted favourable for microbial growth in the different types of

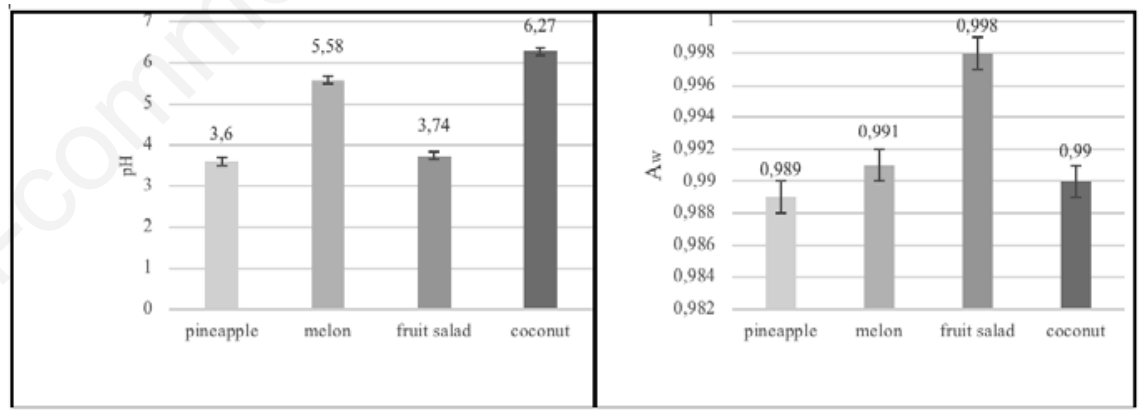

Figure 1. pH and Water Activity (Aw) on RTE fruits.

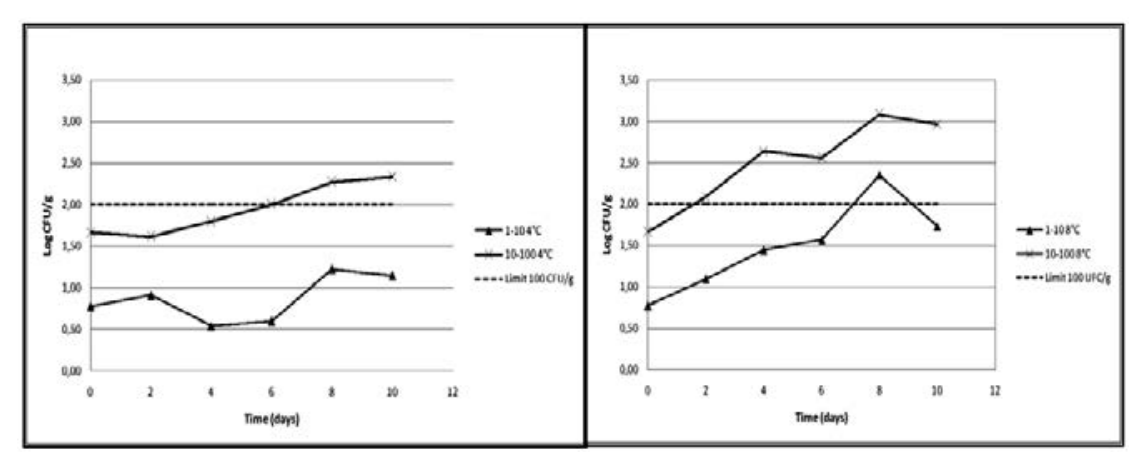

Figure 2. Growth dynamics of $L$. monocytogenes on cantaloupe melon at 4 and $8^{\circ} \mathrm{C}$

products examined. On the contrary, the lower hydrogenionic concentration values determined in more acid fruits, particularly RTE pineapple and fruit salad, inhibited $L$. monocytogenes growth, confirming the results reported by Abadias and Sinigallia (Abadias, Usall, Anguera, Solsona, \& Viñas, 2008; Sinigallia, Bevilacqua, Campaniello, D'Amato, \& Corbo, 2006).

$E$. coli counts resulted below the detec-

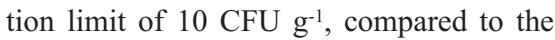
counts observed by other authors (Mukherjee, Speh, Dyck, \&Diez-Gonzalez, 2004; Loncarevic, Johannessen, \& Rørvik, 2005; Mukherjee, Speh, Dyck, \& DiezGonzalez, 2007; Bohaychuk et al., 2009).

Salmonella and L. monocytogenes were not detected (absence in $25 \mathrm{~g}$ ) according to Sagoo (Sagoo, Little, \& Mitchell, 2001; Sagoo, Little, Ward, Gillespie, \& Mitchell, 2003) and McMahon (McMahon \&Wilson, 2001) in organic vegetables, while other authors have detected these microorganisms in fruit (Sagoo, Little \& Mitchell, 2004).

As for the Challenge test results, a negative $\delta$ was obtained for pineapple and fruit salad $\left(-0.52\right.$ and -0.59 at $4^{\circ} \mathrm{C}$ and -0.55 and -0.69 at $8^{\circ} \mathrm{C}$ respectively), therefore considered as not supporting L. monocytogenes growth. Only melon (both varieties analysed) was shown to support L. monocytogenes growth $\left(0.58\right.$ and 0.13 at $4^{\circ} \mathrm{C}$ and 1.50 and 0.97 at $8^{\circ} \mathrm{C}$ in honeydew and can- 
taloupe melons respectively (Table 2).

Moreover, the cantaloupe melon showed values $>0.5 \log 10$ (0.97) when stored at temperatures of $8^{\circ} \mathrm{C}$, while $\delta$ remains below this limit $\left(0.13 / 4^{\circ} \mathrm{C}\right)$ when the melon is maintained at the correct refrigeration temperatures (Figure 3). Particular attention is required with respect to good manufacturing practices, transport and refrigeration of the product on the part of both producer and consumer.

The initial load (at T0, both 1-10 and 10-100 CFU/g concentrations) of inoculated L. monocytogenes decreases over time for pineapple (Figure 3) and for fruit salad (Figure 4). Honeydew melon was found to be an excellent growth substrate for $L$. monocytogenes even at low temperatures (Figure 5). Cantaloupe melon has proved to be a supportive food if maintained for longer times at $4^{\circ} \mathrm{C}$ (Figure 2). It reached $\delta=0.66(\mathrm{~T} 5 / 10-100)$ on the eighth day and even $\delta=1.57$ (T4/1-10) and $\delta=1.57$ (T4/10$100)$ if refrigerated at $8^{\circ} \mathrm{C}$ (Table 2).

Concerning fresh-cut cantaloupe, refrigeration temperatures are fundamental for the development of $L$. monocytogenes. At $4{ }^{\circ} \mathrm{C}$ in fact its growth is limited if the recommended consumption times are respected. On the other hand, if the temperature is higher $\left(8^{\circ} \mathrm{C}\right)$ or if the product is consumed after 4 days, the risk is increased.

Fresh-cut coconut has a growth potential of 0.02 at $4^{\circ} \mathrm{C}$ and 0.41 at $8^{\circ} \mathrm{C}$ showing that the coconut stored at $8^{\circ} \mathrm{C}$ (Table 2) could support growth, while at lower temperatures it allowed survival but did not support L. monocytogenes growth.

Fresh-cut coconut (Table 2) showed very similar $\delta$ values both at the end of the shelf-life period and several days after inoculation (0.02 vs. 0.09 at T3/1-10) if stored at the correct temperature of $4^{\circ} \mathrm{C}$. This data show that coconut is not a great substrate for L. monocytogenes, but it is able to keep the bacterium alive for several days. Instead, at higher temperatures $\left(8^{\circ} \mathrm{C}\right)$, the $L$. monocytogenes present in the coconut were easily able to replicate up to and exceeding the permitted limits (Figure 6). L. monocytogenes reaches $\delta=0.78 \log 10 \mathrm{CFU} / \mathrm{g}$ on the tenth day $(\mathrm{T} 5 / 10-100)$ at $8^{\circ} \mathrm{C}$ (Table 2).

In pineapple and fruit salad, the initial load (at T0) of inoculated L. monocytogenes decreases over time, both at 4 and $8^{\circ} \mathrm{C}$.

In outbreaks related to food consumption, as reported by Gaul et al., 2013, a low level of L. monocytogenes contamination is required to affect individuals, predominantly the elderly and immunosuppressed persons. So, as confirmed by our data, starting from a very low concentration (inoculum 110), L. monocytogenes is capable of rapidly replicating at low temperatures. For these

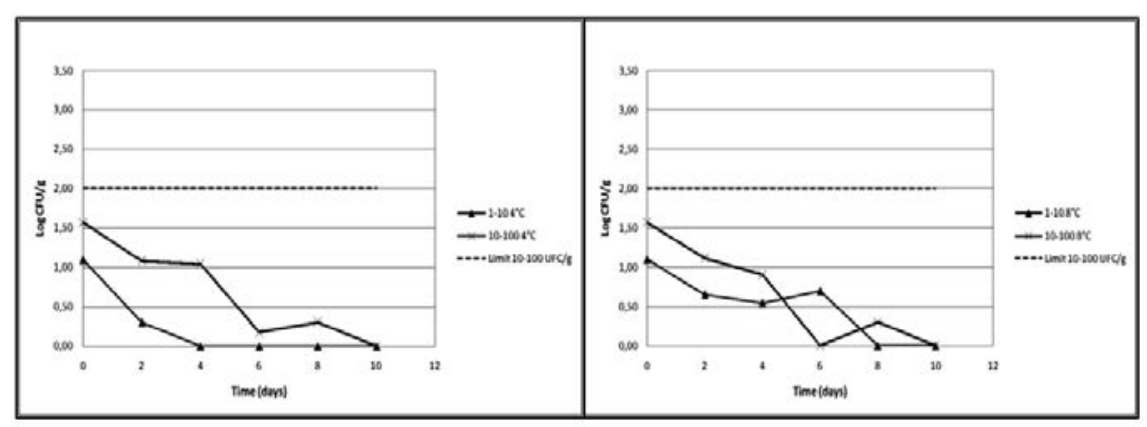

Figure 3. Growth dynamics of $L$. monocytogenes on pineapple at 4 and $8^{\circ} \mathrm{C}$.

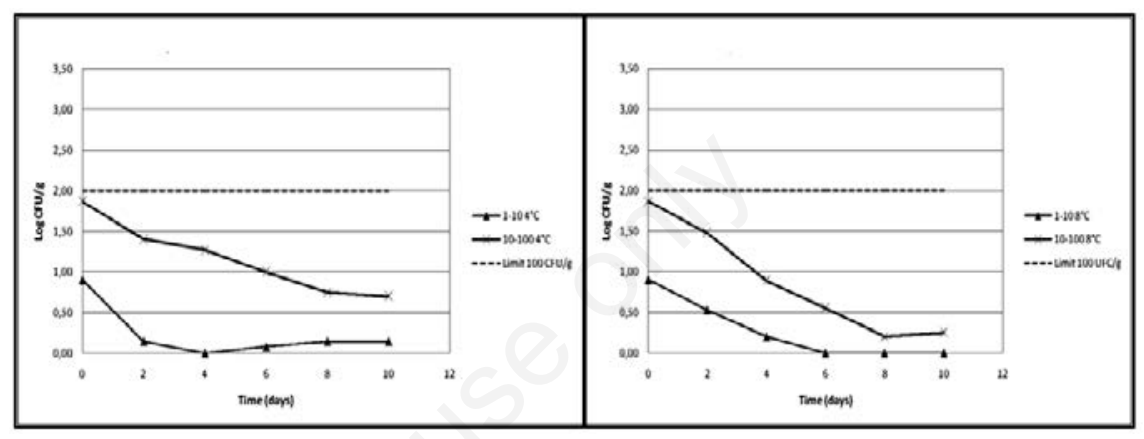

Figure 4. Growth dynamics of $L$. monocytogenes on fruit salad at 4 and $8^{\circ} \mathrm{C}$

reasons, RTE food matrices like coconut or melon could be a health risk even at a low

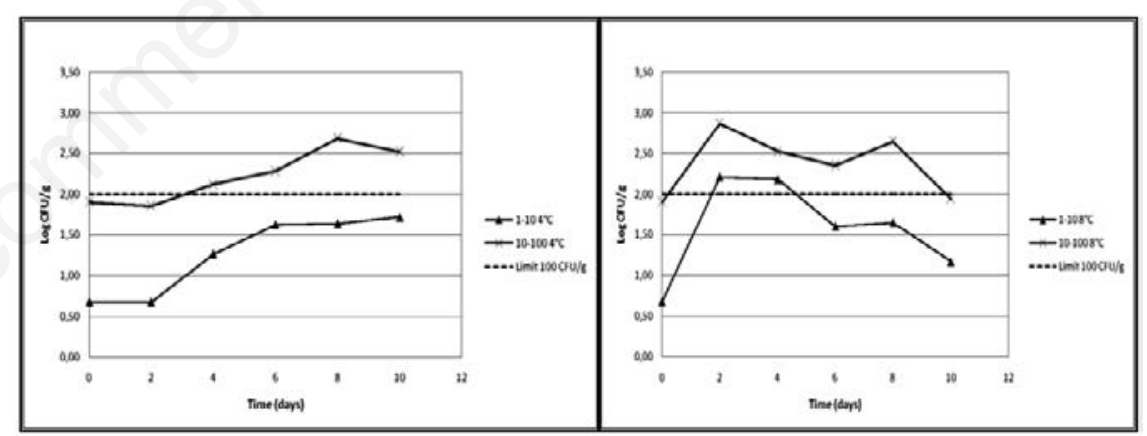

Figure 5. Growth dynamics of $L$. monocytogenes on honeydew melon at 4 and $8{ }^{\circ} \mathrm{C}$.

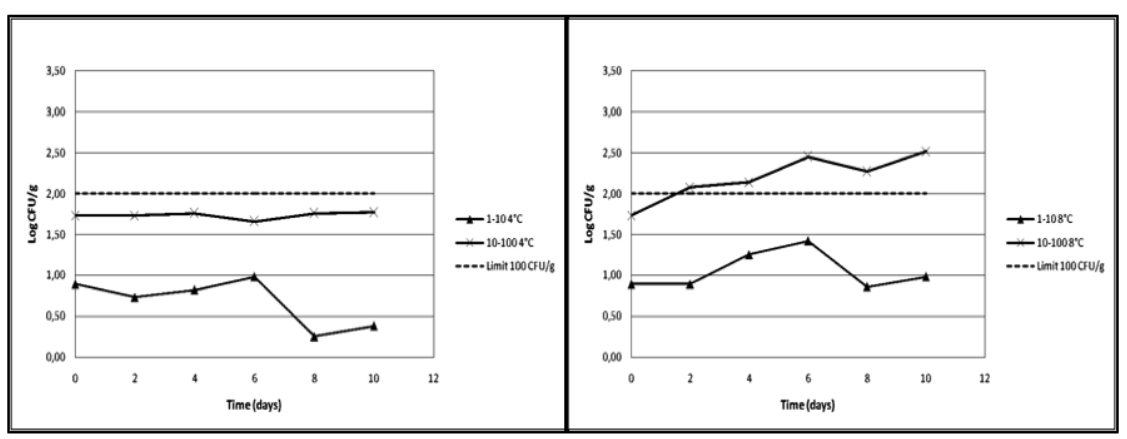

Figure 6. Growth dynamics of $L$. monocytogenes on coconut at 4 and $8^{\circ} \mathrm{C}$. 
infective dose of $L$. monocytogenes. However, criteria for growth and no-growth of $L$. monocytogenes in RTE foods for risk assessment is would be limited. It is necessary in fact, to consider this risk as dependent on the expiration date of the product including storage conditions and spoilage.

These findings are valuable if we consider the average temperatures of household refrigerators, which maintain values often closer to $8-10^{\circ} \mathrm{C}$ than $4^{\circ} \mathrm{C}$. Some authors (Roccato, Uyttendaele, \& Membré, 2017; Chang \& Hsu, 2008) have discussed storage temperature by consumers as being one of the critical points along the food chain. The consumer often does not respect the manufacturer's instructions for consumption for different reasons (distraction, economic reasons, tendency not to waste food and others).

\section{Conclusions}

Our study highlighted the potential risk of contamination by L. monocytogenes in particular categories of foods which are increasingly consumed nowadays. Some fruit allow the bacteria to replicate very easily, while others totally block its growth.

The microbiological quality of the fruit was overall satisfactory, probably related to the use of high- quality raw materials, respect for the cold chain and good hygiene practices.

From our findings it is possible to state that RTE products such as fruit salad or pineapple can be safer in terms of the risk associated with the presence of L. monocytogenes, while fresh-cut coconut and especially fresh-cut melon (both our types) should be considered as risk products.

A low initial load also derived from good hygiene practices and correct storage temperatures are essential to reduce bacterial growth in RTE fruit, in particular referring to consumer behaviour, a domestic level with refrigeration temperatures closer to $8^{\circ} \mathrm{C}$ instead of the desirable $4^{\circ} \mathrm{C}$, it could to further minimize the risk associated with growth of L. monocytogenes.

On the other hand, if one considers the structural specificity and high availability in terms of nutrients that melon is able to offer as a substrate for microbial growth, the different producers of fresh-cut fruit should package melons together with acid fruits (i.e. melon with pineapple or kiwi, etc.). Such a combination would result in products whose water activity value $\left(\mathrm{a}_{\mathrm{W}}\right)$ is very high, but in which the $\mathrm{pH}$ value obtained is low enough to prevent the development of L. monocytogenes, thereby reducing the risk to the consumer.
Each kind of RTE fruit has a different commercial life based on its specific Growth Potential (Ziegler, Rüegg, Stephan \& Guldimann, 2018) and food should be stored at temperature no higher than 4 degrees for a short period within up production time and shelf life.

\section{References}

Abadias M, Usall J, Anguera M, Solsona C, Viñas I, 2008. Microbiological quality of fresh, minimally processed fruit and vegetables, and sprouts from retail establishments. Int J Food Microbiol 123:121-9.

Angelo KM, Jackson KA, Wong KK, Hoekstra RM, Jackson BR, 2016. Assessment of the Incubation Period for Invasive Listeriosis. Clin Infect Dis 63:1487-9.

Angelo KM, Conrad AR, Saupe A, 2017. Multistate outbreak of Listeria monocytogenes infections linked to whole apples used in commercially produced, prepackaged caramel apples: United States, 2014-2015. Epidemiol Infect 145:848-56.

Bae D, Seo KS, Zhang T, Wang C, 2013. Characterization of a potential Listeria monocytogenes virulence factor associated with attachment to fresh produce. Appl Environ Microbiol 79:6855-61.

Bartholomew MJ, Vose DJ, Tollefson LR, Travis CC, 2005. A linear model for managing the risk of antimicrobial resistance originating in food animals. Risk Anal 99-108.

Beaufort A, Bergis H, Lardeux AL, Lombard B, 2014. EURL Lm technical guidance document for conducting shelf-life studies on Listeria monocytogenes in ready-to-eat foods. Appl Environ Microbiol 74:594-604.

Bencardino D, Vitali LA, Petrelli D, 2018. Microbiological evaluation of ready-toeat iceberg lettuce during shelf-life and effectiveness of household washing methods. Ital J Food Safety 7:6913.

Beuchat LR, 1996. Pathogenic Microorganisms Associated with Fresh Produce. J Food Prot 59:204-16.

Bohaychuk VM, Bradbury RW, Dimock R, 2009. A microbiological survey of selected Alberta-grown fresh produce from farmers' markets in Alberta, Canada. J Food Prot 72:415-20.

Buchanan RL, Gorris LGM, Hayman MM, Jackson TC, Whiting RC, 2017. A review of Listeria monocytogenes: An update on outbreaks, virulence, doseresponse, ecology, and risk assessments. Food Control 2017;75.
Commission Regulation (EC) No 1441/2007. (2007). Amending Regulation (EC) No 2073/2005 on microbiological criteria for food stuffs.

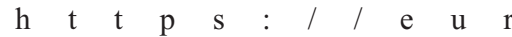
lex.europa.eu/LexUriServ/LexUriServ. do?uri=OJ:L:2007:322:0012:0029:EN: PDF. Accessed 15 June 2020.

Coroneo V, Carraro V, Aissani N, 2016 Detection of Virulence Genes and Growth Potential in Listeria monocytogenes Strains Isolated from Ricotta Salata Cheese. J Food Sci 81:M114-20.

Chang JI, Hsu TE, 2008. Effects of compositions on food waste composting. Bioresour Technol 99:8068-74.

Dussurget O, Pizarro-Cerda J, Cossart P, 2004. Molecular determinants of Listeria monocytogenes virulence. Annu Rev Microbiol 58:587-610.

European Centre for Disease Prevention and Control (ECDC). 2018. Annual Epidemiological ReportListeriosis.https ://www.ecdc.europa.eu/sites/default/file s/documents/surveillance-antimicrobial-resistance-Europe-2018.pdf. Accessed 3September 2020.

Francois K, Valero A, Geeraerd AH, Van Impe JF, Debevere J, Gardia-Gimeno RM, Zurera G, Devlieghere F, 2007. Effect of preincubation temperature and $\mathrm{pH}$ on the individual cell lag phase of Listeria monocytogenes cultured at refrigeration temperatures. Food Microbiol 24:32-43.

Gnanou Besse N, Beaufort A, Rudelle S, Denis C, Lombard B, 2008. Evaluation of an enumeration method for Listeria monocytogenes at low contamination levels in cold-smoked salmon. Int J Food Microbiol 124:271-4.

Hwang CA, Marmer BS, 2007. Growth of Listeria monocytogenes in egg salad and pasta salad formulated with mayonnaise of various $\mathrm{pH}$ and stored at refrigerated and abused temperatures. Food Microbiol 24:211-1.

Loncarevic S, Johannessen GS, Rørvik LM, 2005. Bacteriological quality of organically grown leaf lettuce in Norway. Lett Appl Microbiol 41:186-9.

Marras L, Carraro V, Sanna C, Sanna A, Ingianni A, Coroneo V, 2019. Growth of Listeriamonocytogenes in ready to eat salads at different storage temperatures and valuation of virulence genes expression. Ann Ig 31:374-84.

McCollum JT, Cronquist AB, Silk BJ, 2013. Multistate outbreak of listeriosis associated with cantaloupe. N Engl J Med 369:944-53.

McMahon MA, Wilson IG, 2001. The occurrence of enteric pathogens and Aeromonas species in organic vegeta- 
bles. Int J Food Microbiol 70:155-62.

Mukherjee A, Speh D, Dyck E, DiezGonzalez F, 2004. Preharvest evaluation of coliforms, Escherichia coli, Salmonella, and Escherichia coli O157:H7 in organic and conventional produce grown by Minnesota farmers. J Food Prot 67:894-900.

Mukherjee A, Speh D, Diez-Gonzalez F, 2007. Association of farm management practices with risk of Escherichia coli contamination in pre-harvest produce grown in Minnesota and Wisconsin. Int J Food Microbiol 120:296-302.

Ricci A, Allende A, Bolton D, Chemaly M, Davies R, 2018. Listeria monocytogenes contamination of ready-to-eat foods and the risk for human health. Available from: https://efsa.onlinelibrary.wiley.com/doi/full/10.2903/j.efsa. 2018.5134.

Roccato A, Uyttendaele M, Membré JM, 2017. Analysis of domestic refrigerator temperatures and home storage time distributions for shelf-life studies and food safety risk assessment. Food Res Int 96:171-81.

Sagoo SK, Little CL, Mitchell RT, 2001. The microbiological examination of ready-to-eat organic vegetables from retail establishments in the United Kingdom. Lett Appl Microbiol 33:4349.

Sagoo SK, Little CL, Ward L, Gillespie IA, Mitchell RT, 2003. Microbiological study of ready-to-eat salad vegetables from retail establishments uncovers a national outbreak of $\mathrm{s}$ a l mone 1 losis. J Food Prot 66:403-9.

Salazar JK, Sahu SN, Hildebrandt IM, 2017. Growth Kinetics of Listeria monocytogenes in Cut Produce. J Food Prot 80:1328-36.

Sheng L, Edwards K, Tsai HC, Hanrahan I, Zhu MJ, 2017. Fate of Listeria monocytogenes on Fresh Apples under
Different Storage Temperatures. Front Microbiol 8:1396.

Silva S, Teixeira P, Oliveira R, Azeredo J, 2008. Adhesion to and viability of Listeria monocytogenes on food contact surfaces. J Food Prot 71:1379-85.

Taormina PJ, Beuchat LR, 2002. Survival of Listeria monocytogenes in commercial food-processing equipment cleaning solutions and subsequent sensitivity to sanitizers and heat. J Appl Microbiol 92:71-80.

Ziegler M, Rüegg S, Stephan R, Guldimann C, 2018. Growth potential of Listeria monocytogenes in six different RTE fruit products: impact of food matrix, storage temperature and shelf life. Ital J Food Safety 7:7581.

Zhu Q, Gooneratne R, Hussain MA, 2017. Listeria monocytogenes in Fresh Produce: Outbreaks, Prevalence and Contamination Levels. Foods 2017;6:21. 